\title{
Biological Evaluation of Anti-androgenic Effect of Some Plant Foods
}

\author{
Mohamed M. Rashed ${ }^{1}$, Magdy Shallan ${ }^{1}$, Doha A. Mohamed ${ }^{2, *}$, Karem Fouda ${ }^{2}$, Laila M. Hanna ${ }^{2}$ \\ ${ }^{1}$ Biochemistry Department, Faculty of Agriculture, Cairo University, Cairo, Egypt \\ ${ }^{2}$ Food Sciences and Nutrition Department, National Research Centre, Dokki, Cairo, Egypt \\ *Corresponding author: dohamohamed@yahoo.com
}

Received August 05, 2014; Revised September 05, 2014; Accepted September 16, 2014

\begin{abstract}
The present study was carried out to evaluate the anti-androgenic effect of flax (Linum usitatissimum L.), sesame (Sesamum indicum), safflower seed (Carthamus tinctorius) and soybean (Glycine max L.) seeds in form of petroleum ether, ethanol extracts [(300 mg. $\mathrm{kg}^{-1}$ rat body weight)] and whole powder ( $20 \%$ in the diet) using prostate weight method in castrated rats. The safety of the studied plants' was evaluated through determination of liver and kidney functions. Chemical compositions of the studied plants clarified that the highest content of fat (52.5\%) and ash (7.5\%) were present in sesame seeds, while safflower seeds showed the highest content of crude fiber (11.8\%) and carbohydrate (37.8\%) also soybean contains high percentage of protein (41.2\%). Sesame seeds showed the highest content of total phenolic compound (196.55 mg GAE/100 g), while soybean showed the lowest content (132.5 mg GAE/100 g). Fatty acids analysis revealed that oleic acid was present only in sesame seed oil (66.74\%). Linolenic acid ( $\omega-3)(55.77 \%)$ was the major fatty acid in flaxseed oil. Soybean oil showed the highest content of linoleic acid ( $\omega-6)$ (69.84\%). All studied plants' oil contains stigmasterol and $\beta$-sitosterol. Safflower seed oil showed the highest content of campesterol (9.02\%). Administration of different studied plants' to castrated rats produced reduction in prostate weight and significant reduction in testosterone level with variable degrees. All studied plants' showed complete safety towards liver and kidney function. In conclusion, all studied plants could be used as new potential therapeutic candidate for the treatment of androgen-related diseases.
\end{abstract}

\section{Keywords: antiandrogen, flaxseed, sesame seeds, safflower seeds, soybean seeds, castrated rats}

Cite This Article: Mohamed M. Rashed, Magdy Shallan, Doha A. Mohamed, Karem Fouda, and Laila M. Hanna, "Biological Evaluation of Anti-androgenic Effect of Some Plant Foods." Journal of Food and Nutrition Research, vol. 2, no. 9 (2014): 645-651. doi: 10.12691/jfnr-2-9-19.

\section{Introduction}

Androgens play a critical role in the development of the normal male phenotype [1]. An androgen antagonist (antiandrogen) can broadly be defined as any compound that has the biological effect of blocking or suppressing the action of male sex hormones such as testosterone within the human body. Anti-androgens are an assorted group of drugs and compounds that reduce the levels or activity of androgen hormones within the human body [2]. Androgens themselves have a diverse range of effects in both males and females and their dys-regulation can give rise to a variety of clinical disorders, including polycystic ovarian syndrome, the most common endocrine disorder in females, which affects up to $7 \%$ of the population, hirsutism, acne vulgaris, male pattern baldness benign prostatic hyperplasia (BPH), and endocrine related cancers such as carcinoma of the prostate [2]. Androgen-related diseases impair the well-being of many aging men. Unfortunately, the medications used to treat these diseases have many side effects. For example, finasteride, a synthesized $5 \alpha$-reductase inhibitor, can cause side effects such as gynecomastia and severe myopathy because of its similar structure to that of the steroidal hormones [2]. Therefore, there is a significant need for the development of novel drugs to treat androgen-related diseases [3]. The presence of anti-androgenic phyto-chemicals in plants, herbs, and food stuffs provides an alternative to modern synthetic pharmaceuticals. It is also commonly believed that there are fewer adverse effects of such alternative therapies [2]. Anti-androgens can exhibit their activity both on a peripheral and a central site. They compete with the peripheral androgen receptors and thus inhibit the effect of endogenous or exogenous androgens. Inhibition of $5 \alpha$-reductase is considered to be a mechanism [4]. Phytoestrogens are defined as plant-derived compounds with estrogen like activities according to their chemical structures and activities [5,6]. Because of the similar molecular structures between phytoestrogens and endogenous steroid hormones, these phytoestrogens may have similar functions in our body [7]. Exposure to low doses of phytoestrogens in the perinatal period affects Leydig cell function in adult rats, causing a decrease in testicular testosterone secretion [8]. Logically, any treatment that could decrease androgen hormone action would have great potential in addressing prostate disorders, such as BPH or prostate cancer. Therefore, the objective of the present study is the evaluation of the anti- 
androgenic effect of petroleum ether and ethanol extracts of flaxseed, sesame seeds, safflower seeds and soybean seeds. Also the anti-androgenic effect of the powder form of the studied plants' was evaluated. Fatty acids, phytosterols and total phenolic contents of the studied plants were also assessed.

\section{Materials and Methods}

\subsection{Materials}

Plant materials: Flaxseed (Linum usitatissimum L.), sesame seed (Sesamum indicum), safflower seed (Carthamus tinctorius) and soybean (Glycine max L.) were purchased from Agriculture Research Centre, Giza, Egypt.

Animals: Male albino rats, immature, weight 54.4 \pm 5.4 g were used in the present study. Animals were obtained from the animal house of National Research Centre, Cairo, Egypt. The animals were kept individually in stainless steel cages at temperature $24 \pm 2^{\circ} \mathrm{C}$, a relative humidity of $55 \pm 10 \%$, and a $12 \mathrm{~h}$ light cycle/12 h dark cycle. Water and food were given ad-libitum.

\subsection{Methods}

Chemical analysis of powder mixtures. Powder mixtures samples were dried in an air-circulated oven at $40^{\circ} \mathrm{C}$ till complete dryness (Heraeus 6060, Thermo Scientific company, USA) and sieved through 100-mesh sieve. The samples were analyzed for moisture, protein, fat, crude fiber and ash contents using AOAC [9] standard procedure.

Determination of total phenolic contents. Total phenolics were determined colorimetrically in the powder plant mixtures using Folin-Ciocalteu reagent [10]. Absorbance was measured at $765 \mathrm{~nm}$ using UV-2700 spectrophotometer (Shimadzu, USA). The total phenolic content was expressed as gallic acid equivalents (GAE) in mg. $100 g^{-1}$ dry material.

Preparation of diets: Different experimental diets were used in the study as shown in Table 1. Salt mixture and vitamin mixtures were prepared according to Briggs and Williams [11] and Morcos [12], respectively. Oil soluble vitamins were given orally in a dose of $0.1{\mathrm{ml} . \mathrm{rat}^{-1}}^{-1}$ per week.

Table 1. Composition of different experimental diets (g/100 g)

\begin{tabular}{|c|c|c|c|c|c|}
\hline \multirow{2}{*}{ Ingredients } & \multicolumn{5}{|c|}{ Diets } \\
\cline { 2 - 6 } & Control & \multicolumn{5}{|c|}{ Sesame } & \multicolumn{1}{c|}{ Soybean } & \multicolumn{1}{c|}{ Safflower } & Flaxseed \\
\hline Casein & 12 & 8.16 & 3.76 & 8.36 & 8.41 \\
Corn oil & 10 & - & 5.8 & 4.54 & 2.09 \\
Sucrose & 23.5 & 21.4 & 20.98 & 19.9 & 20.7 \\
Starch & 47 & 42.94 & 41.96 & 39.7 & 41.3 \\
Salt mix. & 3.5 & 3.5 & 3.5 & 3.5 & 3.5 \\
Vitamin Mix. & 1 & 1 & 1 & 1 & 1 \\
Fiber & 3 & 3 & 3 & 3 & 3 \\
Sesame seeds & - & 20 & - & - & - \\
Soybean & - & - & 20 & - & - \\
Safflower & - & - & - & 20 & - \\
seeds & - & - & - & - & 20 \\
Flaxseed & - & - & - &
\end{tabular}

Preparation of plants extracts: The air-dried powdered of flaxseed, sesame seeds, safflower seeds and soybean seeds were extracted successively in a continuous extraction apparatus (Soxhlet) until exhaustion with petroleum ether $\left(40-60^{\circ} \mathrm{C}\right)$, then ethanol. The solvent of each extract was completely removed by evaporation under reduced pressure at a temperature not exceeding $40^{\circ} \mathrm{C}$. All extracts were kept in deep-freeze till used.

Assessment of fatty acids, hydrocarbons and phytosterols contents in extracts mixtures. The unsaponifiable fraction and fatty acid methyl esters of the studied petroleum ether extracts of flaxseed, sesame seeds, safflower seeds and soybean were prepared according to AOAC [9] to be subjected to GLC analysis of fatty acids, hydrocarbons and phytosterols.

The unsaponifiable fraction was analyzed by GLC adopting the following conditions: Column: 10\% OV-101 packed column; Stationary phase: Chromosorb W-HP; Detector temperature: $290^{\circ} \mathrm{C}$; Injector temperature, $28^{\circ} \mathrm{C}$; Carrier gas $\mathrm{N}_{2}$; flow-rate $30 \mathrm{ml} / \mathrm{min}$; air flow-rate: 300 $\mathrm{ml} / \mathrm{min} ; \mathrm{H}_{2}$ Flow-rate $30 \mathrm{ml} / \mathrm{min}$; Detector FID; Chart speed: $0.5 \mathrm{~cm} / \mathrm{min}$; Oven program: Initial temperature, $70^{\circ} \mathrm{C}$; Final temperature, $270^{\circ} \mathrm{C}$; programmed $4^{\circ} \mathrm{C} / \mathrm{min}$. For $35 \mathrm{~min}$ at $270^{\circ} \mathrm{C}$, total time, $85 \mathrm{~min}$. Identification of hydrocarbons and sterols contents of the unsaponifiable matter was carried out by comparison of their retention times with co-injected authentic reference compounds. Quantization was based on peak area integration.

Analysis by GLC of the methyl ester was carried out according to the following conditions: Stationary phase: 10\% diethylene glycosuccinate (DEGS) packed column; oven temperature, $170^{\circ} \mathrm{C}$; detector temperature, $300^{\circ} \mathrm{C}$; injector temperature, $250^{\circ} \mathrm{C}$; Carrier gas, $\mathrm{N}_{2}$; flow-rate, 30 $\mathrm{ml} / \mathrm{min}$; air flow-rate, $350 \mathrm{ml} / \mathrm{min} ; \mathrm{H}_{2}$ flow-rate, 350 $\mathrm{ml} / \mathrm{min}$; detector, FID; Chart speed, $2 \mathrm{~cm} / \mathrm{min}$. Identification of the fatty acid methyl ester was carried out by direct comparison of retention times of each of the separated compounds with authentic samples of the fatty acid methyl esters analyzed under the same conditions. Quantization was based on peak area integration.

Preparation of dosage form. Petroleum ether extracts and ethanol extracts of different plants under study were dispersed separately in water using gum acacia to be given orally to rats. For the control, the vehicle was prepared through dissolving the same amount of gum acacia in water.

Design of the experimental study. Anti-androgenic activity of all plants powders and extracts under study was evaluated in castrated rats according to the method of Kim et al. [13]. Eighty four male rats were divided into 14 groups, 6 rats per each. Group one was served as normal control. All rats were castrated except normal group. Group two was served as positive control. The other 12 groups were served as test groups. Starting one day after surgery, the rats were injected subcutaneously for ten days with testosterone propionate $\left(0.15 \mu \mathrm{g} \cdot \mathrm{kg}^{-1}\right.$ rat body weight). Groups 3 and 4 were fed on balanced diet and given daily oral dose of flaxseed petroleum or ethanol extract (300 mg. kg ${ }^{-1}$ rat body weight). Group 5 was fed on balanced diet containing 20\% of flaxseed powder. Groups 6 and 7 were fed on balanced diet and given daily oral dose of sesame petroleum or ethanol extract (300 mg. $\mathrm{kg}^{-1}$ rat body weight). Group 8 was fed on balanced diet containing 20\% of sesame powder. Groups 9 and 10 were fed on balanced diet and given daily oral dose of safflower petroleum or ethanol extract (300 mg. $\mathrm{kg}^{-1}$ rat body weight). Group 11 was fed on balanced diet containing $20 \%$ of safflower powder. Groups 12 and 13 were fed on balanced diet and given daily oral dose of soybean 
petroleum or ethanol extract (300 mg. $\mathrm{kg}^{-1}$ rat body weight). Group 14 was fed on balanced diet containing $20 \%$ of soybean powder. At the end of the study (the $11^{\text {th }}$ day) total food intake, body weight gain and feed efficiency ratio were calculated. Blood samples were collected for the determination of plasma total cholesterol [14]. The plasma levels of creatinine [15] and urea [16] were determined as indicator of kidney function, while the activity of aspartate transaminase (AST) and alanine transaminase (ALT) [17] were determined as indicator of liver function. Also plasma level of testosterone was determined in all samples using ELISA technique [18]. Also the ventral prostate was removed and weighed.

Animal procedures were performed in accordance with the Ethics Committee of the National Research Centre, Cairo, Egypt, and followed the recommendations of the National Institutes of Health Guide for Care and Use of Laboratory Animals (Publication No. 85-23, revised 1985).

Statistical analysis. The results of animal experiments were expressed as the Mean \pm SE and they were analyzed statistically using the one-way analysis of variance ANOVA followed by Duncan's test.

\section{Results}

Table 2. Chemical composition of the tested plant seeds powder mixtures

\begin{tabular}{|c|c|c|c|c|}
\hline Ingredients/100g dry sample & Flaxseed & Sesame seeds & Safflower seeds & Soybean seeds \\
\hline Protein (g) & $17.9 \pm 0.072$ & $19.2 \pm 0.289$ & $18.2 \pm 0.145$ & $41.2 \pm 0.260$ \\
Fat (g) & $39.6 \pm 0.733$ & $52.5 \pm 0.606$ & $27.6 \pm 0.208$ & $21 \pm 0.231$ \\
Ash (g) & $7.5 \pm 0.052$ & $5.9 \pm 0.058$ & $4.6 \pm 0.173$ & $6.2 \pm 0.058$ \\
Crude fibers (g) & $9 \pm 0.471$ & $2 \pm 0.115$ & $11.8 \pm 0.173$ & $6.7 \pm 0.289$ \\
Carbohydrate* & $26 \pm 0.139$ & $20.4 \pm 0.463$ & $37.8 \pm 0.233$ & $24.9 \pm 0.418$ \\
\hline
\end{tabular}

* Calculated by differences

Chemical compositions of the plants under study (Table 2) clarified that soybean contains high percentage of protein $(41.2 \%)$. Sesame seeds showed the highest content of fat $(52.5 \%)$ followed by flaxseed (39.6\%). Safflower seeds showed the highest content of crude fiber (11.8\%) followed by flaxseed (9\%). Ash was present as $7.5 \%$, $5.9 \%, 4.6 \%$ and $6.2 \%$ in flaxseed, sesame seeds, safflower and soybean, respectively. Percentage carbohydrate was
26\%, 20.4\%, 37.8\% and 24.9\% in flaxseed, sesame seeds, safflower seeds and soybean seeds, respectively. Table 3 showed the contents of total phenolic as [mg GAE. ${ }^{-1}$ dry weight] of different studied plants. Sesame seeds showed the highest content of total phenolic compound (196.55 GAE.g $\left.{ }^{-1}\right)$ followed by safflower seeds (183.38 mg GAE/100 g). Soybean showed the lowest content of phenolic compounds (132.5 GAE.100 g ${ }^{-1}$ ).

Table 3. Total phenolic contents of the studied plants

\begin{tabular}{|c|c|}
\hline Plants & Total phenolic (mg GAE. 100g-1) \\
\hline Flaxseed & $178.25 \pm 3.055$ \\
Sesame seeds & $196.55 \pm 2.09$ \\
Safflower seeds & $183.38 \pm 2.55$ \\
Soybean & $132.5 \pm 1.07$ \\
\hline
\end{tabular}

Table 4. Fatty acids contents of the different studied plants (as percentage of total fatty acids)

\begin{tabular}{|c|c|c|c|c|}
\hline Fatty acids & Flaxseed & Sesame seed & Safflower seed & Soybean seed \\
\hline C16 (0) & 6.333 & 11.316 & 12.729 & 15.207 \\
\hline C18 (1) & - & 66.743 & - & - \\
\hline C18(2) & - & 0.929 & 44.486 & 69.837 \\
\hline C18 (3) & 50.771 & 0.710 & 4.765 & - \\
\hline C20 (0) & 5.812 & 15.309 & 4.299 & 1.141 \\
\hline C22 (0) & 5.818 & 3.854 & 0.041 & - \\
\hline Total identified saturated fatty acids & 17.963 & 26.625 & 17.069 & 16.348 \\
\hline Total identified unsaturated fatty acids & 50.771 & 68.382 & 49.251 & 69.837 \\
\hline
\end{tabular}

Table 5. GLC analysis of unsaponifiable matter of the different plants (as percentage of total unsaponifiable matter)

\begin{tabular}{|c|c|c|c|c|}
\hline Hydrocarbon \& sterols & Flaxseed & Sesame seed & Safflower seed & Soybean seed \\
\hline $\begin{array}{c}\text { Hydrocarbon: } \\
\text { Pentadecane (C15) } \\
\text { Hexadecane (C16) } \\
\text { Heptadecane (C17) } \\
\text { Octadecane (C18) } \\
\text { Nonadecane (C19) } \\
\text { Eicosane (C20) } \\
\text { Heneicosane (C21) } \\
\text { Docosane (C22) } \\
\text { Tricosane (C23) } \\
\text { Tetracosane (C24) } \\
\text { Pentacosane (C25) } \\
\text { Nonacosane (C28) } \\
\text { Phytosterols: } \\
\text { Campesterol } \\
\text { Stigmasterol } \\
\beta \text {-Sitosterol } \\
\text { Total identified hydrocarbon } \\
\text { Total identified Phytosterol }\end{array}$ & $\begin{array}{c}- \\
0.612 \\
0.195 \\
0.869 \\
0.509 \\
2.465 \\
4.871 \\
1.615 \\
1.205 \\
2.025 \\
4.706 \\
13.267 \\
\\
3.599 \\
7.085 \\
21.058 \\
32.333 \\
31.742\end{array}$ & $\begin{array}{c}0.171 \\
0.346 \\
0.838 \\
0.699 \\
0.506 \\
1.163 \\
4.103 \\
1.338 \\
2.727 \\
- \\
3.711 \\
12.223 \\
\\
- \\
28.958 \\
27.199 \\
27.958 \\
56.157\end{array}$ & $\begin{array}{c}0.170 \\
0.243 \\
0.378 \\
0.538 \\
0.796 \\
0.769 \\
3.737 \\
1.343 \\
3.825 \\
- \\
- \\
19.483 \\
\\
9.017 \\
5.175 \\
6.793 \\
31.282 \\
20.985\end{array}$ & $\begin{array}{c}0.241 \\
0.584 \\
0.516 \\
2.167 \\
1.064 \\
1.106 \\
5.629 \\
1.278 \\
0.737 \\
2.606 \\
- \\
- \\
\\
8.103 \\
3.349 \\
6.317 \\
15.928 \\
17.769\end{array}$ \\
\hline
\end{tabular}


Table 4 and Table 5 showed the fatty acids and unsaponifiable matter in the petroleum ether extract (oil) of different plants under investigation, respectively. The results of fatty acids analysis revealed that palmetic acid was the major saturated fatty acid in all studied oils. Sesame seed oil showed the highest content of saturated fatty acids (26.625\%). Oleic acid was present only in sesame seed oil by $66.743 \%$. Linolenic acid $(\omega-3)$ (55.771\%) was the major unsaturated fatty acid in flaxseed oil. Soybean oil showed the highest content of linoleic acid ( $\omega-6)$ (69.837) followed by safflower seed oil (44.486). Unsaturated fatty acids were ranged from $49.251 \%$ in safflower seed oil to $69.837 \%$ in soybean oil. GLC investigation of the unsaponifiable matter showed the presence of stigmasterol and $\beta$-sitosterol in all the studied oils. Sesame seed oil showed the highest content of stigmasterol and $\beta$-sitosterol. Safflower seed oil showed the highest content of campesterol (9.017\%). Total phytosterol was ranged from $17.769 \%$ in soybean oil to $56.157 \%$ in sesame seed oil. Flaxseed oil showed the highest content of hydrocarbon 32.333\%, while soybean showed the lowest content of hydrocarbons $15.928 \%$.

Plasma level of testosterone and prostate weight as indicator of anti-androgenic effect of different experimental groups are shown in Table 6. Plasma levels of different castrated rats were elevated significantly compared with negative control. Also prostate weight of all castrated rats was elevated significantly compared with negative control. Oral administration of ethanol extract of different plants under study showed significant reduction in testosterone level and prostate weight compared with different petroleum ether extracts and positive control. Feeding castrated immature rats on balanced diet containing $20 \%$ powder of flaxseed, sesame seeds, safflower seeds and soybean showed significant reduction in testosterone level and prostate weight compared with different petroleum ether extracts and positive control. Oral administration of sesame seeds ethanol extract showed the highest reduction in testosterone level (-58). Ethanol extract of safflower seeds showed the highest reduction in prostate weight $(-48)$.

Table 6. Plasma testosterone level and prostate weight of different experimental groups (Mean \pm SE) as indicator of anti-androgenic effect

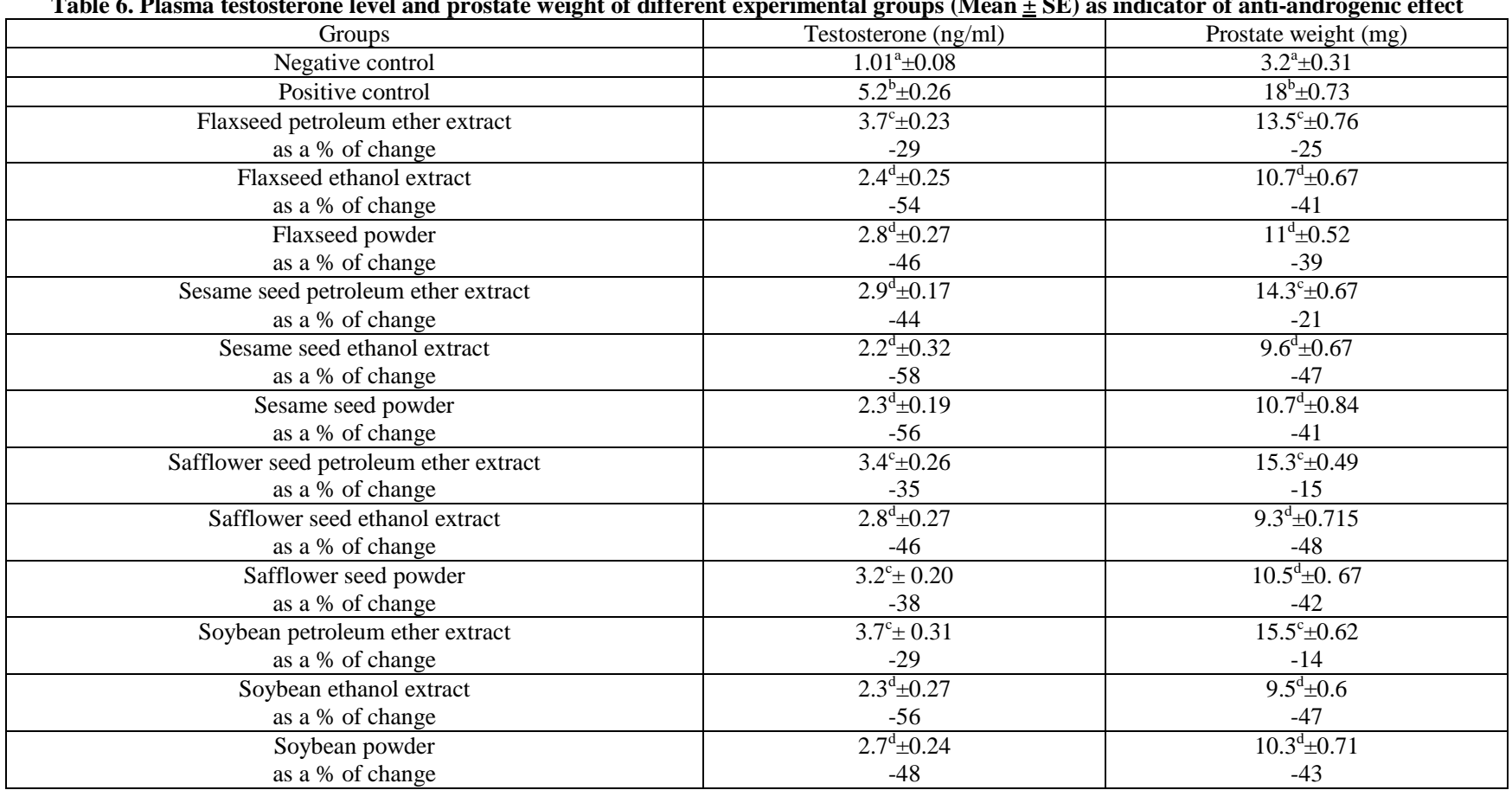

The same letters in each column means non-significant difference while different letter means significant difference at $\mathrm{p}<0.05$.

Table 7. Plasma cholesterol level, liver and kidney function of different experimental groups (Mean \pm SE)

\begin{tabular}{|c|c|c|c|c|c|}
\hline Groups & Cholesterol (mg.dl $\left.{ }^{-1}\right)$ & Creatinine $\left(\mathrm{mg} \cdot \mathrm{dl}^{-1}\right)$ & Urea $\left(\mathrm{mg} \cdot \mathrm{dl}^{-1}\right)$ & $\operatorname{AST}\left({\mathrm{U} . \mathrm{l}^{-1}}^{-1}\right)$ & $\operatorname{ALT}\left(\mathrm{U}^{-l^{-1}}\right)$ \\
\hline Negative control & $85.1^{\mathrm{a}} \pm 1.02$ & $0.403^{\mathrm{a}} \pm 0.01$ & $33.2^{\mathrm{a}} \pm 1.13$ & $92.7^{\mathrm{a}} \pm 3.49$ & $26.2^{\mathrm{a}} \pm 1.14$ \\
\hline Positive control & $88.9^{\mathrm{a}} \pm 1.61$ & $0.46^{\mathrm{a}} \pm 0.01$ & $35.8^{\mathrm{a}} \pm 0.68$ & $95^{\mathrm{a}} \pm 3.01$ & $28.3^{\mathrm{a}} \pm 1.45$ \\
\hline Flaxseed petroleum ether extract & $86.2^{\mathrm{a}} \pm 1.09$ & $0.42^{\mathrm{a}} \pm 0.02$ & $32.7^{\mathrm{a}} \pm 1.04$ & $95.2^{\mathrm{a}} \pm 3.44$ & $26.7^{\mathrm{a}} \pm 0.88$ \\
\hline Flaxseed ethanol extract & $86.5^{\mathrm{a}} \pm 0.86$ & $0.43^{\mathrm{a}} \pm 0.015$ & $33.8^{\mathrm{a}} \pm 0.88$ & $93.3^{\mathrm{a}} \pm 3.26$ & $27.5^{\mathrm{a}} \pm 0.56$ \\
\hline Flaxseed powder & $85.6^{\mathrm{a}} \pm 1.74$ & $0.45^{\mathrm{a}} \pm 0.013$ & $32.9^{\mathrm{a}} \pm 0.83$ & $94.2^{\mathrm{a}} \pm 3.68$ & $27^{\mathrm{a}} \pm 1.24$ \\
\hline Sesame seed petroleum ether extract & $87.1^{\mathrm{a}} \pm 1.14$ & $0.44^{\mathrm{a}} \pm 0.021$ & $33.9^{\mathrm{a}} \pm 0.81$ & $96.7^{\mathrm{a}} \pm 2.7$ & $27.7^{\mathrm{a}} \pm 1.28$ \\
\hline Sesame seed ethanol extract & $85.8^{\mathrm{a}} \pm 1.37$ & $0.4^{\mathrm{a}} \pm 0.016$ & $32.7^{\mathrm{a}} \pm 1.16$ & $94^{\mathrm{a}} \pm 4.38$ & $28.7^{\mathrm{a}} \pm 1.33$ \\
\hline Sesame seed powder & $84.5^{\mathrm{a}} \pm 2.47$ & $0.42^{\mathrm{a}} \pm 0.009$ & $33.3^{\mathrm{a}} \pm 0.93$ & $93.8^{\mathrm{a}} \pm 1.90$ & $26.7^{\mathrm{a}} \pm 2.23$ \\
\hline Safflower seed petroleum ether extract & $87.4^{\mathrm{a}} \pm 1.89$ & $0.42^{\mathrm{a}} \pm 0.016$ & $33.0^{\mathrm{a}} \pm 1.47$ & $97.5^{\mathrm{a}} \pm 4.70$ & $28.8^{\mathrm{a}} \pm 1.25$ \\
\hline Safflower seed ethanol extract & $88.8^{\mathrm{a}} \pm 1.65$ & $0.41^{\mathrm{a}} \pm 0.016$ & $33.1^{\mathrm{a}} \pm 0.79$ & $96.3^{\mathrm{a}} \pm 3.76$ & $27.3^{\mathrm{a}} \pm 1.41$ \\
\hline Safflower seed powder & $86.9^{\mathrm{a}} \pm 1.54$ & $0.41^{\mathrm{a}} \pm 0.02$ & $33.2^{\mathrm{a}} \pm 2.02$ & $94^{\mathrm{a}} \pm 1.99$ & $27.8^{\mathrm{a}} \pm 1.90$ \\
\hline Soybean petroleum ether extract & $86.4^{\mathrm{a}} \pm 1.97$ & $0.43^{\mathrm{a}} \pm 0.04$ & $32.8^{\mathrm{a}} \pm 1.29$ & $96.2^{\mathrm{a}} \pm 2.23$ & $26.8^{\mathrm{a}} \pm 0.87$ \\
\hline Soybean ethanol extract & $85.4^{\mathrm{a}} \pm 1.66$ & $0.42^{\mathrm{a}} \pm 0.012$ & $33.4^{\mathrm{a}} \pm 1.14$ & $96.8^{\mathrm{a}} \pm 2.59$ & $27.8^{\mathrm{a}} \pm 1.38$ \\
\hline Soybean powder & $85.6^{\mathrm{a}} \pm 1.76$ & $0.47^{\mathrm{a}} \pm 0.026$ & $33.3^{\mathrm{a}} \pm 1.09$ & $95^{\mathrm{a}} \pm 3.18$ & $29.3^{\mathrm{a}} \pm 1.17$ \\
\hline
\end{tabular}

The same letters in each column means non-significant difference while different letter means significant difference at $\mathrm{p}<0.05$. 
Table 8. Nutritional parameters of different experimental groups (Mean $\pm \mathrm{SE}$ )

\begin{tabular}{|c|c|c|c|c|c|}
\hline Groups & $\begin{array}{l}\text { Initial body weight } \\
\text { (g) }\end{array}$ & $\begin{array}{l}\text { Final body weight } \\
\text { (g) }\end{array}$ & $\begin{array}{l}\text { Body weight gain } \\
\text { (g) }\end{array}$ & $\begin{array}{l}\text { Total food intake } \\
\text { (g) }\end{array}$ & $\begin{array}{c}\text { Food efficiency } \\
\text { ratio }\end{array}$ \\
\hline Negative control & $54.3^{\mathrm{a}} \pm 1.11$ & $86.5^{\mathrm{a}} \pm 6.8$ & $32.2^{\mathrm{a}} \pm 6.5$ & $110.5^{\mathrm{a}} \pm 4.2$ & $0.289^{\mathrm{a}} \pm 0.06$ \\
\hline Positive control & $54.2^{\mathrm{a}} \pm 3.32$ & $82.7^{\mathrm{a}} \pm 2.7$ & $28.4^{\mathrm{a}} \pm 3.1$ & $104.0^{\mathrm{a}} \pm 3.9$ & $0.274^{\mathrm{a}} \pm 0.03$ \\
\hline Flaxseed petroleum ether extract & $54.5^{\mathrm{a}} \pm 2.69$ & $86.7^{\mathrm{a}} \pm 3.4$ & $32.2^{\mathrm{a}} \pm 1.8$ & $112.4^{\mathrm{a}} \pm 2$ & $0.287^{\mathrm{a}} \pm 0.02$ \\
\hline Flaxseed ethanol extract & $54.6^{\mathrm{a}} \pm 3.3$ & $85.3^{\mathrm{a}} \pm 6.8$ & $30.7^{\mathrm{a}} \pm 4.1$ & $107.3^{\mathrm{a}} \pm 4.8$ & $0.284^{\mathrm{a}} \pm 0.03$ \\
\hline Flaxseed powder & $54.1^{\mathrm{a}} \pm 2.6$ & $85.3^{\mathrm{a}} \pm 5.1$ & $31.2^{\mathrm{a}} \pm 4.7$ & $112.8^{\mathrm{a}} \pm 4.9$ & $0.274^{\mathrm{a}} \pm 0.04$ \\
\hline $\begin{array}{c}\text { Sesame seed petroleum ether } \\
\text { extract }\end{array}$ & $54.7^{\mathrm{a}} \pm 1.8$ & $81.8^{\mathrm{a}} \pm 2.4$ & $27.1^{\mathrm{a}} \pm 1.2$ & $110.8 \pm 2.6$ & $0.246^{\mathrm{a}} \pm 0.02$ \\
\hline Sesame seed ethanol extract & $54.7^{\mathrm{a}} \pm 1.2$ & $87.3^{\mathrm{a}} \pm 3.9$ & $32.6^{\mathrm{a}} \pm 3.6$ & $113.3^{\mathrm{a}} \pm 3.5$ & $0.286^{\mathrm{a}} \pm 0.03$ \\
\hline Sesame seed powder & $54.8^{\mathrm{a}} \pm 2.7$ & $81.6^{\mathrm{a}} \pm 2.7$ & $26.8^{\mathrm{a}} \pm 1.5$ & $106.4^{\mathrm{a}} \pm 2.7$ & $0.251^{\mathrm{a}} \pm 0.01$ \\
\hline $\begin{array}{l}\text { Safflower seed petroleum ether } \\
\text { extract }\end{array}$ & $54.0^{\mathrm{a}} \pm 1.4$ & $81.6^{\mathrm{a}} \pm 3.7$ & $27.6^{\mathrm{a}} \pm 3.4$ & $106.4^{\mathrm{a}} \pm 3.5$ & $0.261^{\mathrm{a}} \pm 0.04$ \\
\hline Safflower seed ethanol extract & $54.7^{\mathrm{a}} \pm 2.7$ & $81.8^{\mathrm{a}} \pm 1.6$ & $27.1^{\mathrm{a}} \pm 1.7$ & $107.7^{\mathrm{a}} \pm 4.5$ & $0.253^{\mathrm{a}} \pm 0.01$ \\
\hline Safflower seed powder & $54.1^{\mathrm{a}} \pm 3.2$ & $79.5^{\mathrm{a}} \pm 3.4$ & $25.3^{\mathrm{a}} \pm 1.2$ & $103.3^{\mathrm{a}} \pm 3.3$ & $0.245^{\mathrm{a}} \pm 0.01$ \\
\hline Soybean petroleum ether extract & $54.7^{\mathrm{a}} \pm 1.9$ & $83.6^{\mathrm{a}} \pm 2.3$ & $28.9^{\mathrm{a}} \pm 1.6$ & $104.9^{\mathrm{a}} \pm 4.9$ & $0.277^{\mathrm{a}} \pm 0.01$ \\
\hline Soybean ethanol extract & $54.1^{\mathrm{a}} \pm 2.2$ & $80.2^{\mathrm{a}} \pm 2.6$ & $26.1^{\mathrm{a}} \pm 1.5$ & $106.3^{\mathrm{a}} \pm 3.6$ & $0.246^{\mathrm{a}} \pm 0.01$ \\
\hline Soybean powder & $54.4^{\mathrm{a}} \pm 1.9$ & $79.5^{\mathrm{a}} \pm 1.5$ & $25.1^{\mathrm{a}} \pm 0.8$ & $103.7^{\mathrm{a}} \pm 3.1$ & $0.242^{\mathrm{a}} \pm 0.01$ \\
\hline
\end{tabular}

The same letters in each column means non-significant difference while different letter means significant difference at $\mathrm{p}<0.05$.

Plasma cholesterol level, liver and kidney function of different experimental groups are shown in Table 7. Plasma levels of creatinine and urea, as indicator to kidney function, plasma cholesterol and activity of ALT and AST showed non-significant changes in all experimental groups. Non-significant elevation of liver and kidney function in different experimental groups revealed the complete safety of the studied plants in form of extracts and powder. All studied nutritional parameters (Table 8) showed nonsignificant changes in different groups.

\section{Discussion}

Androgens not only play an important role in the development and function of the prostate but they are also intimately involved in the development and progression of benign prostate hyperplasia and prostate cancer [19]. Testosterone is the most abundant circulating androgen, and can be converted to dihydrotestosterone (DHT), a more potent androgen, by the $5 \alpha$-reductase enzymes in target tissues [20]. Within the prostate, testosterone is converted to the more potent androgen DHT via the action of $5 \alpha$-reductase enzymes. DHT is the primary prostatic androgen and promotes the growth and survival of normal, hyperplastic and malignant prostate tissues. Specific inhibition of $5 \alpha$-reductase may reduce the production of DHT in the prostate while maintaining other endogenous hormone levels [19].

In the present study flaxseed, sesame seeds, safflower seeds and soybean seeds showed significant antiandrogenic effect with different degrees. The antiandrogenic activity of the studied plants may be attributed to the presence of fatty acids and phenolic compounds such as lignans and flavonoids, which play an important role as phytoestrogens.

The presence of anti-androgenic phyto-chemicals in plants, herbs, and food stuffs provides an alternative to modern synthetic pharmaceuticals. It is also commonly believed that there are fewer adverse effects of such alternative therapies [2]. Plant oils have been suggested as an alternative and less aggressive option to synthetic drugs for BPH [21]. Anti-androgens can exhibit their activity both on a peripheral and a central site. They compete with the peripheral androgen receptors and thus inhibit the effect of endogenous or exogenous androgens. Inhibition of 5alpha-reductase is considered to be a mechanism to inhibit BPH [4]. Phytoestrogens are a diverse group of nonsteroidal compounds synthesized by plants. The major classes of phytoestrogens are the isoflavones and lignans found at high levels in legumes such as soybean, chickpea and in various plant parts, including roots, stems, leaves, flowers, fruits and seeds. Of more than 1000 types of isoflavones, genistein and daidzein are the most commonly investigated isoflavones [22]. Plant lignans are generally categorized as phytoestrogens, lignan has been shown to reduce testosterone (total and free), and $5 \alpha$ reductase, the enzyme which converts testosterone to its most active form, dihydrotestosterone [23]. Lignans are found in whole grains (especially in the bran layer) and seeds (in the seed coat). Barley, buckwheat, flaxseed, millet, oats, rye, sesame seeds and wheat contain fairly high levels of lignans. Nuts and legumes including soybeans [24] are also reasonably good sources. Although in lesser amounts than in grains, lignans are also present in fruits and vegetables such as asparagus, grapes, kiwi fruit, lemons, oranges, pineapple, wine and even in coffee and tea $[25,26]$.

In the present study castrated rats feeding on diet containing $20 \%$ flaxseed powder or given oral administration of petroleum ether or ethanol extract of flaxseed showed significant reduction in prostate weight and testosterone level with different degrees. Flaxseed consumption in various forms as a food ingredient and for its medicinal properties dates from 500 BC since its cultivation [27]. It is therefore not surprising that flaxseed is the most prominent oilseed studied to date as a functional food, since it is a leading source of $\alpha$-linolenic acid (52\% of total fatty acids) and of phenolic compounds known as lignans [28]. Flaxseed is an important source of lignan secoisolariciresinol diglucoside (SDG) and its aglycone, secoisolariciresinol (SECO). These phenolic compounds can be metabolized to the mammalian lignans enterodiol (ED) and enterolactone (EL) by human intestinal microflora. Flaxseed lignans are known for their potential health benefits, which are attributed to their antioxidant and phytoestrogenic properties [29]. These and other components of flaxseed incorporation in the diet are particularly attractive for the development of foods with specific health advantages. Flaxseed has been shown to reduce androgen levels in men with prostate cancer [30].

In the present study ethanol extract of safflower seeds and sesame seeds showed the highest anti-androgenic activity as revealed by reduction in prostate weight and 
testosterone level. Safflower seeds contain numerous polyphenolic compounds such as lignans, glucosides, flavonoids and serotonins. The chemical structures and antioxidant properties of these compounds have been characterized [31]. These compounds, termed phytoestrogens, are known to have weak estrogenic or antiestrogenic activity towards mammals [32]. Ethanolic extract of safflower is the most active $5 \alpha$-reductase inhibitor [33]. Sesame plant is one of the richest food sources of lignans, a major type of phytoestrogens known to man since the dawn of civilization [34] and is increasingly being incorporated into human diets because of its reported health benefits. Sesame, which is a plant with both medicinal and nutritive values, is popularly used as an herbal remedy against a wide range of ailments. Sesame seed is not only a good source of edible nutrients, but is also widely considered to have medicinal value that includes antioxidant, anti-ageing, antimutagenic, antihypertensive, and anti-inflammatory activities, as well as the ability to inhibit cholesterol absorption from the intestine and synthesis in the liver. The seed is used as a diuretic, emollient, and a tonic for the liver and kidneys [35]. Sesame lignans such as sesamin, episesamin, sesamolin, and $\gamma$-tocopherol isolated from Sesamum indicum and Sesamum radiatum seeds among other species have been implicated as having estrogenic and/or anti-estrogenic [36] and antioxidant [36] properties. Moreover, the ROS scavenging moiety of sesame lignans was reported to protect body cells from the free radical injury [37]. Sesame seeds showed beneficial effect for menopausal women confirms the possible phytoestrogenic properties of its lignans through their interaction with sex steroids [38].

Legumes are present in almost every diet throughout the world, and in addition to the seeds many other parts of the plant are also edible. The legume attracting much attention recently is soybean, which contains high concentrations of the isoflavones daidzein and genistein. These compounds are further metabolized to equol, enterodiol, and enterolactone by intestinal bacteria [39]. Isoflavones are considered as phytoestrogens that mimic the hormone $17 \beta$-estradiol (E2).

The fatty acid profiles of all studied plants oils by GLC revealed the presence of a mixture of saturated and unsaturated fatty acids. It was reported that certain aliphatic unsaturated fatty acids had an inhibitory activity on human or rat microsomal 5 - $\alpha$-reductase enzyme, on the other hand [40] found that saturated fatty acids such as lauric and myristic acids inhibit 5- $\alpha$-reductase enzyme. These results were also obtained by [41] who reported that both lauric and myristic acids were good inhibitors for 5$\alpha$-reductase 2 , while oleic and linoleic were active as inhibitors of 5 - $\alpha$-reductase.

\section{Conclusion}

The present research indicated that administration of different studied plants' to castrated rats produced reduction in prostate weight and significant reduction in testosterone level with variable degrees. All studied plants' showed complete safety towards liver and kidney function. The present research indicated that all studied plants possessed anti-androgenic activity in castrated rats so it may be used as new potential therapeutic candidate for the treatment of androgen-related diseases.

\section{Statement of Competing Interests}

The authors have no competing interests.

\section{Acknowledgements}

The authors thank the National Research Centre, Cairo, Egypt for financing this work. This research is a part of PhD thesis (No. 3/4/7) and totally funded by National Research Centre, Cairo, Egypt.

\section{References}

[1] Svechnikov, K., Izzo, G., Landreh, L., Weisser, J. and Söder, O, Endocrine disrupts and Leydig cell function, J. Biomed. Biotechnol., 1-10, 2010.

[2] Grant, P. and Ramasamy S, An Update on Plant Derived AntiAndrogens. Int. J. Endocrinol. Metab., 10 (2), 497-502, 2012.

[3] Chiu, H.W., Chen, M.H., Fang, W.H., Hung, C.M., Chen, Y.L., Wu, M.D., Yuan, G.F., Wu, M.J. and Wang, Y.J, Preventive effects of Monascus on androgen-related diseases: androgenetic alopecia, benign prostatic hyperplasia, and prostate cancer. $J$. Agric. Food Chem., 61 (18), 4379-4386, 2013.

[4] Akamine, K., Koyama, T. and Yazawa, K, Banana peel extract suppressed prostate gland enlargement in testosterone-treated mice. Biosci. Biotechnol. Biochem., 73, 1911-1914, 2009.

[5] Jin, J.S., Lee, J.H. and Hattori, M, Ligand Binding Affinities of Arctigenin and Its Demethylated Metabolites to Estrogen Receptor Alpha. Molecules, 18, 1122-1127, 2013.

[6] Roca, P., Sastre-Serra, J., Nadal-Serrano, M., Pons, D.G., Blanquer-Rossello, M.D. and Oliver, J, Phytoestrogens and Mitochondrial Biogenesis in Breast Cancer. Influence of Estrogen Receptors Ratio. Curr. Pharm. Des., 270 (1), 261-268, 2014.

[7] Kim, S.H. and Choi, K.C, Anti-cancer Effect and Underlying Mechanism(s) of Kaempferol, a Phytoestrogen, on the Regulation of Apoptosis in Diverse Cancer Cell Models. Toxicol. Res., 29 (4), 229-234, 2013.

[8] Akingbemi, B.T., Braden, T.D., Kemppainen, B.W., Hancock, K.D., Sherrill, J.D. and Cook, S.J, Exposure to phytoestrogens in the perinatal period affects androgen secretion by testicular Leydig cells in the adult rat. Endocrinology, 148, 4475-4488, 2007.

[9] AOAC. Official Methods of Analysis. $16^{\text {th }}$ ed. Association of Official Analytical Chemists International, Arlington, Virginia, 2000.

[10] Singleton, V.L. and Rossi, J.A, Colorimetry of total phenolics with phosphomolybdic-phosphotungstic acid reagents. Am. J. Enol. Vitic., 16, 144-158, 1965.

[11] Briggs, G.M. and Williams, M.A, A new mineral mixture for experimental rat diets and evaluation of other mineral mixtures. Fed. Proc., 22, 261-266, 1963.

[12] Morcos, S.R, The effect of protein value of the diet on the neurological manifestations produced in rats by $\beta$ immodipropionitrile. Br. J. Nutr., 21, 269-274, 1967.

[13] Kim, H.S., Han, S.Y., Kim, T.S., Kwack, S.J., Lee, R.D., Kim, I.Y., Seok, J.H., Lee, B.M., Yoo, S.D. and Park, K.L, No androgenic/anti-androgenic effects of bisphenol-A in Hershberger assay using immature castrated rats. Toxicol. Lett., 135 (1-2), 11123, 2002.

[14] Watson, D, A simple method for the determination of serum cholesterol. Clin. Chem. Acta., 5, 637-642, 1960.

[15] Houot, O, Interpretation of Clinical Laboratory Tests (eds. G. Siest, J. Henny, F. Schiele, D.S. young), Biomedical Publications, 1985, p. 250.

[16] Fawcett, J.K. and Scott, J.E, A rapid and precise method for the determination of urea. J. Clin. Pathol., 13, 156-159, 1960.

[17] Reitman, S. and Frankel, S, Colorimetric methods for aspartate and alanine aminotransferase. Am. J. Clin. Path., 28, 55-60, 1957. 
[18] Tietz, N.W. Clinical guide to laboratory tests, $3^{\text {rd }}$ edition, W. B. Saunders, Co., Philadelphia. 578-580, 1995.

[19] Rosenberg, M.T., Froehner, M., Albala, D. and Miner, M.M, Biology and natural history of prostate cancer and the role of chemoprevention. Int. J. Clin. Pract., 64, 1746-1753, 2010.

[20] Nacusi, L.P. and Tindall, D.J., Targeting $5 \alpha$-reductase for prostate cancer prevention and treatment. Nat. Rev. Urol., 8, 378-384, 2011.

[21] Belostotskaia, L.I., Nikitchenko, I.V., Gomon, O.N., Chaǐka, L.A., Bondar, V.V. and Dziuba, V.N, Effect of biologically active substances of animal and plant origin on prooxidant-antioxidant balance in rats with experimental prostatic hyperplasia. Eksp. Klin. Farmakol., 69, 66-68, 2006.

[22] Abarzua, S., Szewczyk, M., Gailus, S., Richter, D.U., Ruth, W., Briese, V. and Piechull, B, Effects of phytoestrogen extracts from Linum usitatissimum on the Jeg3 human trophoblast tumour cell line. Anticancer Research, 27, 2053-2058, 2007.

[23] McCann, M.J., Gill, C.I., McGlynn, H. and Rowland, I.R, Role of mammalian lignans in the prevention and treatment of prostate cancer. Nutr. Cancer, 52, 1-14, 2005.

[24] Penalvo, J.L, Health implications of traditional soymilk. Doctoral Thesis, University Complutense Madrid, Spain, pp 1-317, 2002.

[25] Smeds, A.I., Eklund, P.C., Sjoholm, R.E., Willfor, S.M., Nishibe, S., Deyama, T. and Holmbom, B.R, Quantification of a broad spectrum of lignans in cereals, oilseeds, and nuts. J. Agr. Food Chem., 55, 1337-1346, 2007.

[26] Kuhnle, G.G.C., Dell'Aquila, C., Aspinall, S.M., Runswick, S.A., Mulligan, A.A. and Bingham, S.A, Phytoestrogen content of cereals and cereal-based foods consumed in the UK. Nutrition and Cancer, 61 (3), 302-309, 2009.

[27] Oomah, B.D. and Mazza, G, Flaxseed products for disease prevention in functional foods. in: Biochemical and Processing Aspects (ed. G. Mazza). Technomic Publishing, Lancaster, PA, pp. 91-99, 1998.

[28] Oomah, B.D. and Mazza, G, Bioactive components of flaxseed: occurrence and health benefits. in: Phytochemicals and Phytopharmaceuticals. (eds. F. Shahidi, C.T. Ho.), Champaign: AAOCS Press, pp. 105-112, 2000.

[29] Herchi, W., Arráez-Román, D., Trabelsi, H., Bouali, I., Boukhchina, S., Kallel, H., Segura-Carretero, A. and FernándezGutierrez, A, Phenolic compounds in flaxseed: a review of their properties and analytical methods. An overview of the last decade. J. Oleo Sci., 63 (1), 7-14, 2014.
[30] Debra, A., Nowak, R.N., Denise, C., Snyder, M.S., Ann, J., Brown, M.D. and Wendy Demark-Wahnefried, Ph.D, The Effect of Flaxseed Supplementation on Hormonal Levels Associated with Polycystic Ovarian Syndrome: A Case Study. Curr. Top Nutraceutical Res., 5 (4), 177-181, 2007.

[31] Kim, E.O., Oh, J.H., Lee, S.K., Lee, J.Y. and Choi, S.W, Antioxidant properties and quantification of phenolic compounds from safflower (Carthamus tinctorius L.) seeds. Food Sci. Biotechnol., 16, 71-77, 2007.

[32] Dixon, R.A, Phytoestrogens. Annu. Rev. Plant Biol., 55, 225-261, 2004.

[33] Kumar, N., Rungseevijitprapa, W., Narkkhong, N., Suttajit, M. and Chaiyasut, C, 5 $\alpha$-reductase inhibition and hair growth promotion of some Thai plants traditionally used for hair treatment Journal of Ethnopharmacology, 139 (3), 765-771, 2012.

[34] Thompson, L.U., Robb, P., Serraino, M. and Cheung, F, Mammalian lignan production from various foods. Nutr. Cancer 16, 43-52, 1991

[35] Oyinloye, B.E., Nwozo, S.O., Amah, G.H., Awoyinka, A.O., Ojo, O.A., Ajiboye, B.O. and Tijani, H.A, Prophylactic effect of aqueous extract of Sesamum indicum seeds on ethanol-induced toxicity in male rats. Nutr Res Pract., 8 (1), 54-58, 2014.

[36] Shittu-Lukeman, A.J, The effect of the aqueous crude leaves extract of Sesamum radiatum compared to Mesterolone (proviron) on the adult male Sprague Dawley rats testis and epididymis. MSc Dissertation. Lagos State University, College of Medicine, Ikeja, Nigeria, 2006

[37] Jeng, K.C.G. and Hou, R.C.W, Sesamin and Sesamolin: Nature`s therapeutic lignans. Current Enzymes Inhibition, 1, 11-20, 2005.

[38] Wu, W.H., Kang, Y.P., Wang, N.H., Jou, H.J. and Wang, T.A Sesame ingestion affects sex hormones, antioxidant status, and blood lipids in postmenopausal women. J. Nutr., 136, 1270-1275, 2006.

[39] Liu, W., Tanabe, M., Harada, K.H. and Koizumi, A, Levels of urinary isoflavones and lignan polyphenols in Japanese women. Environ Health Prev Med., 18 (5), 394-400, 2013.

[40] Weisser, H., Tunn, S., Behnke, B. and Krieg, M, Effect of the Sabal serrulata extract IDS 89 and its subfractions on 5- $\alpha$ reductase activity in human benign prostatic hyperplasia. Prostate, 28, 300-306, 1996.

[41] Raynaud, J., Cousse, H. and Martin, P, Inhibition of type 1 and type 25 - $\alpha$-reductase activity by free fatty acids active ingredients of Permixon ${ }^{\circledR}$. J. Steroid Biochem. \& Mol. Biol., 82, 233-239, 2002 